\title{
BEANS BEFORE THE LAW: Knowledge Practices, Responsibility, and the Paraguayan Soy Boom
}

\section{KREGG HETHERINGTON \\ Concordia University}

Soon after I moved into his home in November 2004, I began to consider Antonio a good friend. But late one night in February, during one of his long after-dinner monologues about the various injustices his people suffered, he asked a question that would redefine our relationship. He had been telling me the story of a friend who, while working for a nearby soybean farmer, had contracted a mysterious illness that had made him suddenly swell up and die. Upset by the story, he launched into a rant about soybeans until he was almost shouting above the din of rain on the roof. "You come back in two or three years," Antonio said. "We're all going to be dead. All of the children are going to die. There's no future left for us. It's the soybeans that are killing us." He went on for some time like this, telling similar stories about soybeans and death, and I realized, with some discomfort, that he really meant it. Then, after a brief hesitation, he turned to me and asked, "What do you think of what I just said?" I had a lot more difficulty responding to this question than I like to admit.

At the time, I was researching peasant activism along the conflictive eastern edge of Paraguay's quickly expanding soybean frontier, and Antonio was a local leader in the movement. The sorts of smallholders that followed Antonio did not plant soybeans, a new crop that required significant capital and was associated with wealthier Brazilian migrants entering the area from the east. But the beans were everywhere, and they were transforming the landscape and economy around them. Because I had conceptualized my project around politics and property, I hadn't 
worked out a response to their overwhelming leafy presence. But they never really got under my skin until that night in February, when my response to the beans became inextricably entangled with my responses to Antonio.

I can't remember if I answered his question that night. But the conversation repeated itself many times over the following months, with Antonio and others, and I eventually began to give a standard, tepid answer: the real problem lay in a new agrarian structure developing in rural Paraguay, and the beans were merely incidental, easily replaced by something else, like canola or corn. This answer was not based on evidence or knowledge but on an allegory of agrarian transitions with which I was familiar. Nonetheless it was expressed as expertise, because the question seemed to interpellate me as an expert, as someone asked to give an authoritative opinion about the relationship between someone else's interpretation of the world and the world as I knew it. Only much later did I understand Antonio's hesitation as an invitation: he was not fact-checking but was inviting me to participate in the construction of what would turn out to be a very powerful fact.

The stakes of this difference became clearer to me two weeks later when I had trouble responding again, this time to Andrés, a business consultant whom I knew through wealthy friends in Asunción. Andrés had always been suspicious of my political proclivities and of my motivations for doing research in his country. That night, before dinner at the friend's house, Andrés was reading a newspaper article about a recent campesino (peasant) protest against soybean cultivation. Addressing me gruffly, he proclaimed, "So now your campesinos are afraid of soy!" I had argued with him over the structural causes of rural poverty before, but on this clear challenge to my sympathies, I was unable to respond adequately. Antonio's dire predictions of course came to mind, but I didn't want to share them.

In both of these encounters, the bean presented itself as a curious thing mediating (and potentially reinforcing) a hierarchy of knowledge practices. As I show, it is hard to dispute the correlation between the presence of soybeans in Paraguay and the decline of campesino life on the frontier. Even Andrés could have agreed with that point. But Antonio and others insisted not on correlation but on an explanation of cause and responsibility that violated the tacit ontological rules of a world of human agents and their instruments. They insisted that beans were not merely instruments of human agency or of structural forces but excessive things with a force of their own. And they made this argument earnestly, not only in words but also by attacking soybeans with fire and machetes and scrawling "soy kills" on banners and courthouses. Here they crossed a line that allowed Andrés to disqualify them altogether from the discussion about how to organize Paraguayan 
affairs. In other words, both Andrés and Antonio were asking me to play a part in the triangle in which Paraguayans asserted their modernity vis-à-vis each other by adopting an appropriate relationship with beans. Any analytic response to either question would also already be a political response in a fraught landscape of accusations that at the time I could sense only dimly.

Until this point, I had approached ethnography as an extended discussion with and about humans, and I was less interested in beans than I was with what Antonio said about them. Which meant that it wasn't much of a conversation with humans either. To be blunt, Antonio kept pointing at the beans, and I kept looking at him. I instinctively translated his statements about the nature of beans into social phenomena: I was comfortable saying that this was a figure of speech, a kind of political rhetoric, or even to claim that this is what Antonio believed, all of which explicitly framed "la soja mata" (soy kills) as data for social analysis, rather than analysis itself worthy of response.

The fact that I did not believe that soybeans kill did not entirely prevent me from participating in Antonio's knowledge practices. I was often called on to photograph the negative effects he attributed to beans: dead birds, pustules on babies, abandoned schools, dead crops, burned houses. I didn't sign on to his interpretations of the pictures. Were those birds by the riverbank really poisoned by glyphosate herbicide? Was that kid born without a brain because the neighbor was using a crop duster? And if they were, were beans responsible for these harms? In the absence of laboratory tests (which were impossible to access) or reliable medical opinions (which were always cursory and patronizing), I avoided these questions altogether. It wasn't until June 2005, when I took pictures of two men being shot to death by soy farmers for protesting the soy harvest, that my skepticism was shaken. I became part of the situation, and despite my inability to find intellectual purchase on the beans, I felt compelled to respond more forcefully.

At first, I responded in newspapers, on the radio, and on a number of activist blogs that proliferated around soybeans in 2005. Most of all, though, I responded in court and in a variety of ways that were meant to influence the murder trial that followed the shootings. In this way, I became part of the story that I am about to tell. Although Antonio may have wanted me to lend ethnographic authority to the proposition that beans kill, his greater ambition was to have them affirmed as a legal fact, to enroll the Supreme Court of Paraguay in a process of assigning responsibility for soy's harms, thereby redressing them. And he was partially successful. In the months and years following these conversations, the presence of killer beans was felt by a much broader swath of Paraguayan society, largely through the efforts of 
Antonio and his allies, including, inevitably, myself. This is the story, then, of how Paraguay's killer beans moved from being campesino misunderstandings to matters of national concern. If, as Bruno Latour asserts (1999), facts are produced by "trials of force" inside and outside the laboratory, then this is the story of a different but analogous sort of trial inside and outside the courtroom, which reshaped Paraguay's political territory so that beans might be taken seriously.

\section{MODERN TERRITORY}

Not surprisingly, this confrontation over the status of beans occurred on territory that had been subjected to repeated attempts at modernization and colonization over the past century. Most of the communities in which soybeans are now a threat were built during the late 1960 s and 1970 s as part of a land reform that promised campesinos full political inclusion and economic opportunity in return for desperately hard work in what were then thick forests, inhabited by disparate enclaves of indigenous people and foreign pioneers (see Kleinpenning 1987; Pastore 1972). The project explicitly proposed to turn campesinos into modern subjects by enrolling them in export-oriented cotton production and having them objectify the land as property (see, e.g., Frutos 1982). Eastern Paraguay was transformed during this period into a modern landscape of roads, tamer animals, and self-interested individuals (Domínguez 1975). But it was also modernized in the sense that it became a territory where knowledge practices are captured by categories of difference (Stengers 2008) arranged in a hierarchical and temporal order: indigenous people represented the past, foreigners and elites represented the future, and campesinos struggled to be included in the present (Hetherington 2011).

Perhaps the most striking symptom of this transition is what happened to a host of other creatures who crossed a line from threatening presence into myth and then all but disappeared. Campesino life once included frequent contact with a host of spirit creatures, from the cunning, diminutive pombero to luisõ, the corpse-eating werewolf, but these creatures had begun to disappear in the previous two decades. Older residents of the frontier often lumped these creatures with Guayakí huntergatherers and large forest mammals, and said that they had slowly disappeared "deeper" into the receding forest as the frontier matured. Younger men, however, argued about whether these creatures existed at all or were "just myths." The mythologization was formalized during the 1990s, when the national education system was overhauled by a major World Bank project. The new curriculum included teaching the Guaraní language and classes about cultural heritage that 
prominently featured these creatures as tokens of Paraguay's cultural past. By 2005, the argument that these were just myths was winning out, and certainly Antonio had nothing but amiable dismissal for those who continued to believe in such things, staking his political project and self-representation on the grounds of a firmly modernist ontology.

Thus, the campesino movement that now "fears beans" was forged by young men hewing trees, chasing Indians, and ditching superstitions in return for recognition from a modernizing government. Men like Antonio are hardscrabble frontier individualists deeply suspicious of anything that smells of animism. He has always tried to fight the Paraguayan elite on modern territory: he clearly does not want killer beans to be relegated to the same category as the pombero, who lives comfortably on modern territory as a quaint tradition but not as a political force. Given this, then, Antonio's turn to killer beans is a careful one, and that makes it all the more pressing to ask the questions: Why is it necessary for him to explain things in this way? Why is it necessary to blur the ontological convention of established political contest by invoking the responsibility of beans, when he knows this will open him up to dismissal?

To answer, I had to stop asking what kind of things killer beans were and start asking under what situations and with what kinds of knowledge practices they were constituted. I have found it helpful to compare soy to a less contentious though otherwise similar entity: cotton. The campesino frontier was built primarily on smallholder cotton production, but the crop has been in decline since the 1980s (Baer and Birch 1984). In 2005, the cotton crop around Vaquería, where Antonio lives, failed spectacularly because of drought and low prices, and most campesinos I knew vowed to stop planting from then on. Some still managed to get a fair return from their plots, however, and I asked one of these farmers, Ortega, how he had managed to save his crop from the usual onslaught of pests that accompanied the drought. He told me that his success was about being aware of the needs of his crop at all times. Late at night, Ortega told me, he could hear his cotton crying (hasẽ), and he was unable to sleep. The cry demanded a response, but he lay there helplessly waiting for the sun to come up so that he could strap on his pesticide pack and go tend to the problem. Here the cotton cries for a specific kind of aid on which both Ortega and the cotton have depended for years, but that is never entirely predictable. For when Ortega goes to bed the following night, he will continue to listen, to know cotton's response to his own ministrations. The ability of both Ortega and his cotton plants to respond to each other (their "response-ability") may decide whether either of them is here next year (cf. Haraway 2008). 
Two things about this story are worth noting. The first is that the cotton's cries are constructed through practices of pragmatic intervention in the world, rather than reflection on it. This is the same difference that Ian Hacking (1983) uses to describe scientific experimentation: the real is grasped not through representation but through effective interventions. For Ortega it is a completely misplaced question to ask whether cotton is really crying. He has no theory of crying cotton, and no need for one; all he knows is that he has to respond. Responsibility for the cotton's distress is distributed through a number of possible conditions, some of which he can affect and some of which he cannot: the drought, the actions of his neighbors, his own previous uses of the soil, whether he is using the right pesticide or if the label on the bottle is even correct, or whether the seeds he bought were bad to begin with. As he lies awake at night, he tries to figure out his place in this scenario in the hopes that he might intervene effectively. This may include buying more pesticide, confronting the seed vendor, or joining a march for subsidies. Each of these actions enrolls a certain network of responsibility and elicits new sorts of responses.

Second, a key difference between crying cotton and killer soy is that the former is a proposition that circulates in a smaller network than the latter. That is, crying cotton is a decidedly local phenomenon, and its robustness is connected to its scale (see Law 2011). It is the sort of knowledge that Ortega needs to be a good cotton farmer in his region of eastern Paraguay; he may call on neighbors or family members to help in his interventions, and they will not question the cotton's cries. At most, he might march and ask for subsidies in the form of credit relief, but these are usually framed in populist terms and do not turn on the question of responsibility. Because no one outside of the situation cares about how Ortega relates to cotton, the cotton's cries do not need to conform to any ontological premises that operate outside of local interventions.

It is not a stretch to describe all of agriculture as this kind of communicative waiting game among people, animals, machinery, plants, and weather. Growing crops is about interactions in which each action can be vaguely directed but is always already too implicated in complex processes to have predictable effects. Instead, they elicit responses that cannot be known ahead of time, and it is this mutual responsiveness (what Karen Barad [2007] calls "intra-action") that constitutes them as actors. This is a view of agriculture and knowledge that is not burdened by ontologically stable objects or properties. ${ }^{1}$ Unlike concepts such as “agency," which connote a stable property (Keane 1997; Laidlaw 2010) ${ }^{2}$ and are therefore open to accusations of misattribution, response is not something one is or has but something 
one does in a given situation. It follows that responsibility is less a characteristic of people than a form of description that one offers of the relationships between different actors in an event whose causal sequences are not merely mechanical.

From the 1960s onward, campesinos and cotton plants existed as they did in Paraguay because of a certain responsive relationship with each other, with chemicals and bugs, neighbors and middlemen. As these relationships started to disintegrate in the $1990 \mathrm{~s}$, as cotton prices stopped rebounding at the end of the season, as a boll weevil infestation demanded new chemical responses, as rainfall diminished in response to deforestation, as soybeans pushed up land prices, and as the Paraguayan government stopped responding to campesino demonstrations, cotton not only began to degrade in quality and finally disappear from the landscape but also campesinos suffered crises of confidence in themselves as campesinos. The particular assemblage of smallholders, cotton, and state building was constructed of tenuous interactions with multiple actors constituting each other in a dialogue of responses. In the same way, now, the soybean frontier quickly articulated itself through a series of coordinated responses involving an even wider and more recalcitrant array of forces. From this point of view, Antonio's hesitant question to me was itself a response to a change in agricultural conditions that became contentious only to the extent that it began to circulate at a larger scale and tried to enroll practitioners beyond the local knowledge circles.

It follows, then, that any ethnography about the situation is similarly bound up with the agricultural and political conditions to which it refers, particularly with the project of rescaling, because it invites responses of its own in a new public and distributes responsibility in a slightly new way that may or may not coordinate easily with what campesinos say. That is, it invites us to think not only about analysis as response (e.g., Riles 2006) but also about the responsibility that we may take on as ethnographers for the circumstances we describe. For Karen Barad (2007), this is an ethic of representation that understands all knowledge creation as a form of intra-action with the things being analyzed, ${ }^{3}$ that understands the postulates of any analytic work as responding to elements of the world we have encountered in investigation, and in so doing elicits new responses.

This is where I am inspired by Isabelle Stengers's (2008, 2010b) call for scholars to avoid modern knowledge practices that participate in the capture of errant knowledge practices. Drawing on Gilles Deleuze and Félix Guattari, Stengers sees things like killer beans as potential "lines of flight" from modern territory (Deleuze and Guattari 1988). An ethnography in response to Antonio can be formulated in one of two ways. On the one hand, it can do what I initially did: 
participate in reestablishing the priority of frames of reference by disqualifying the talk of killer beans as, at best, a figure of speech not meant to be taken literally or, at worst, a mistaken reading of the situation caused by a restricted understanding of what was going on (what Andrés would call "ignorance"). On the other hand, it can itself be formulated very much from within the situation, as a proposition addressed to campesinos as the creators of killer beans.

Such a proposition, while affirming the singularity of their practice as being creative, with no obligation to the great narrative that contrasts myth and reason, is not limited to ratifying what they insist on seeing recognized. It is an active proposition that can involve them in sorting out whatever it is they claim, and especially to consider superfluous the claim to the power of disqualification. [Stengers 2010a:23]

It is therefore appropriate that the response I offer here, the proposition I am formulating after so much hesitation of my own, did not initially present itself in representational form but, rather, as situated interventions that arise from both conversations with campesinos and much exposure to soybeans.

\section{AN ETHNOGRAPHY OF BEANS}

Beans didn't scare me at first. Indeed, as a foreigner to the situation that gives rise to killer beans (a Canadian no less), giant fields of soy were a familiar, even a comforting sight. But it took only a few months with Antonio for me to start feeling the menace from those fields. Soon, the sweetish smell of glyphosate, recently applied, and especially the corpselike smell of 2, 4-D mixed with Tordon, could ruin my appetite and make me expect to see people emerge from their homes to show me pustules on their legs and stomachs. The old roads we took between communities, now passing through vast fields, began to feel desolate, and I feared our motorcycles breaking down there far more than in the forest. Eventually, I came to despise the glower of soy farmers driving their tractors down the road, to stay inside when I was woken up by the halogen lights of the harvesters shining in through the boards of our house, and to steer clear of the 18-wheelers, scattering soybeans into the ditches as they headed for the highway. In one of my last interviews with a soybean farmer in Vaquería, when I asked what people thought of Antonio, I was told that they were just waiting for someone to put up the "twenty-five hundred," an allusion to the price of a bullet. And still it wasn't until I saw someone try to shoot Antonio, narrowly missing him but killing two 
of his friends, that I started to feel directly under threat when around Paraguayan soybeans.

Soy has been around for millennia, but what made it into one of the world's most dominant crops in the 20th century was its simultaneous usefulness as a rotation crop for wheat and maize and its complexity as an industrial raw material. Soy was a darling of modernization projects in the United States in the 1920s and in Brazil and Argentina soon after. In these countries, soybeans were always a cash crop dependent on industrial inputs and processing capacity (de Sousa et al. 2008). Paraguay, landlocked and conflictive, and with very little industry well into the 1970s, put its development emphasis instead into cotton, a more appropriate crop for smallholders with few tools. Even in the late 1970s, when Brazilian migrants began to plant soy in the eastern border regions of Paraguay, they did so as part of a separate national economy and regulatory apparatus, using varieties and buying inputs developed in Brazil, asking Brazilian extensionists for advice, and selling their products to the Brazilian market (see Souchaud 2002).

The breakthrough in Paraguay did not come until the introduction of Roundup Ready Soybeans (RR), a genetically modified variety created by Monsanto in the mid-1990s. In Paraguay it had several advantages that made it especially dangerous: at the time it was still illegal to plant genetically modified organisms in Brazil, and so the cheaper RR soy produced in Paraguay was in high demand in the enormous regional market into which it was fed clandestinely. In practice, the sector was unregulated and untaxed, meaning it was also cheaper than its Argentine competitors. And unlike those two countries, where RR soy had less room to expand, in Paraguay the failing cotton economy was ripe for takeover. As cotton and its markets had declined, much of the state agricultural extension work had been replaced by haphazard NGO-financed diversification projects, disarticulating many communities from traditional patronage networks and isolating them from government. When RR soy appeared, giving soy farmers much greater returns and demanding much less labor ${ }^{4}$ they exploded out from the border region into the declining campesino landscape and soon dominated it.

Although the beans came from Argentina, they were carried by Brazilian colonists on the Paraguayan frontier, named Brasiguaios, who were themselves descendants of German immigrants, proud of a farming tradition that cherished hard, round-the-clock work, technical mastery, mechanical intensity, and high-quality production (Souchaud 2002; Wagner 1990). Soybeans domesticated Brasiguaios in a way that they probably could not have domesticated campesinos (cf. Tsing 
n.d.). Campesinos saw the long hours and chemical dependency of soy agriculture as a form of servitude, and they avoided becoming enrolled, except as casual laborers. In those early years, many campesinos operated as though the frontier was still moving. Seeing their cotton declining and a wave of foreigners moving in with heavy equipment, they sold their plots to Brazilian speculators and went in search of new land. As a result, soy advanced extremely quickly, consuming the remaining space on the frontier, concentrating the eastern regions into larger and larger farms, and finally pushing land prices beyond the reach of anyone outside the sector.

By 2004, this tiny landlocked country with no industry to speak of was the world's fourth largest producer of industrial soybeans. They blanketed 200- to 300-thousand new hectares per year. If in the main cities of the country the new crisis was an increase in peripheral slums, for those who stayed in the countryside it was the dramatic and sudden disappearance of forests, schools, fish, and jobs. Rural employment plummeted so dramatically that between 2003 and 2005 day wages for agricultural labor dropped from 15,000 to 8,000 Guaranies (from about $\$ 2.50$ to $\$ 1.30)$. Around Vaquería, whole towns had literally vanished in a matter of years (Fogel and Riquelme 2005).

In the assemblage that coalesces around soybeans in Paraguay, there are clearly a lot of actors who bear some responsibility for the coordinated attack on campesino lives and livelihoods that took place in the 1990s and 2000s. But none by themselves encompass the enormity of what campesinos mean when they say soy kills. In the middle of this network is that nagging thing, not an object or instrument of some malevolent agency, but a thing that exceeds such explanations (Bennett 2010). And it is appropriate to formulate answers to the campesino crisis that address themselves to that thing and its responsibility. In fact, though campesinos were the only ones who said this explicitly at the beginning, once my ethnographic ear was attuned to the question of responsibility, it was easy to hear that many others implicitly attributed responsibility to beans as well.

For instance, most of the Braziguaios with whom I spoke were relatively small producers, owners of 20 to 100 hectares, who had themselves been displaced by land concentration closer to the Brazilian border. They argued that they had no choice about planting soy - that in the climate created by beans their only other choice was the sort of poverty that they saw in campesino communities. And even this choice was made under duress. The structure of debt in Brasiguaio communities, centered on heavy equipment, agrichemicals, and fuel, made them deeply dependent on the owners of grain silos who fronted not only seed and equipment 
but also cash for land acquisitions or takeovers. Campesinos were sympathetic to this reading, telling me that soybeans enslaved Brasiguaios, turned them violent, and eventually killed them as well ("la soja brasilerojukaha”). Antagonism launched against Brasiguaios (and there was plenty of this, often of an overtly xenophobic variety) was always against a collective that involved beans, because most would say that there had been few problems between them before soy.

Government regulators, without the funding or the technical know-how to control the beans' spread, ducked responsibility as well. For the first five years that RR soy was in Paraguay, it was banned by an executive decree with considerable internal support from the Ministry of Agriculture. But government officials never even considered how they might regulate the beans that were already distributed throughout the eastern region and were well-known to be imported in unmarked "white bags." "soja Maradona" after the famous Argentine football player who could wind his way through any defense and even won a World Cup by breaking the rules (Robin 2008:276). By 2004, soybeans accounted for 11 percent of the country's GDP, and it was hard to imagine what would happen to the economy if a major step was taken to limit production, even while they pushed up exchange rates and unemployment. ${ }^{6}$ Even Monsanto managed to successfully argue its own victimhood at the beginning, given the lack of patent protection or legal approval in Paraguay, and the fact that the beans flowed through a black market that generated no revenue for the country.

The difference between these attributions of responsibility and those of campesinos is that they came from the kinds of voices whose rationality is rarely in question — who may in fact define rationality of the kind Andrés values - because they do not explicitly violate the rules of modernist discourse. Campesinos were the ones who rendered this responsibility in explicitly propositional terms, who, in Latour's (2004) terms, became spokespeople for killer beans, even though it meant risking disqualification from national political discourse. By 2005, as the destructive onslaught of beans became more dire, campesinos felt forced to rescale their interventions. Killer beans went from being a descriptive response to a local problem to being a national proposition that demanded a national response. Antonio's question to me, an attempt at gathering practitioners, was only the precursor to a much more dramatic intervention through the Supreme Court, meant to enroll the Paraguayan public as a whole and, through it, potentially the state. In this, campesinos were in new territory and had to develop new kinds of knowledge practices appropriate to a new scale of proposition. 


\section{BEANS BEFORE THE LAW}

There were no good precedents for this kind of appeal to the court, but the legalistic language that Antonio adopted was part of a more general format for social grievances in the post-Cold War period. Since at least the late 1950s, when General Alfredo Stroessner consolidated his dictatorship of Paraguay, the primary apparatus for coordinating propositions into large-scale truths was the Colorado Party, a vast patronage machine that effectively privatized the state and seeped into every aspect of the campesino frontier (see Nickson and Lambert 2002; Turner 1993). Stroessner's ouster in 1989 created room for vibrant national media and a new intellectual culture led by NGOs in the capital city. But by far the largest change was the rise of discourses around the rule of law, centered on a new constitution and several highly publicized human rights cases (see, e.g., White 2004). Fifteen years into the transition, campesinos knew well that in some ways legalism was a more exclusive (and certainly more expensive) way of achieving justice than the old system of patronage. But some campesino groups had had luck taking land disputes to court, and Antonio knew that courts sometimes ruled in surprising ways. As he would say, it was always worth trying for a "favorable response." As their grievances came to center increasingly on soybeans, it seemed an obvious step to try to bring the law to bear on them as well.

Between 2003 and 2006, campesinos spent an immense amount of time and resources on two cases in particular, the strict legal result of which was to find only two people along the entire soybean chain guilty of criminal activity. Because of the purifying processes required by the court, soybeans themselves were not implicated in these crimes. Nonetheless, I argue, it is these cases more than anything else in Paraguayan politics that helped to solidify and expand soybean responsibility. This is because although the law is restrictive in the way it assigns responsibility, the official decision is not exhaustive of all the effects a court can have in redistributing responsibility. Like any fact, the effectiveness of legal facts does not end with their facticity or the sorts of meager redistribution that a court is capable of effecting. Campesinos and their allies understood very well the point made by John Law (2004): all facts are to some degree allegorical and are shadowed by a complexity they cannot name.

Criminal trials are, above all, a complex system of interpretation and distillation meant to produce a certain kind of fact: a version of historical events in which responsibility is clearly distributed (Fuller 1994) and that carries statebacked authority within a specific territory. Although legal facts are produced in a completely different way than scientific ones, they are similar in that they mark the 
point at which a theory of an event achieves some degree of independence from the processes and people that produce them (Latour 2010). A proposition about legal responsibility achieves authority in the same way that all scientific knowledge does, by surviving what Latour (1999) calls "trials of force" in which they compete with other theories. ${ }^{7}$ Such trials come in many different forms, of course, from experimental repetition and peer review to political contest or judicial hearings. But to the extent that a proposition about responsibility results in a favorable court ruling, it, like a scientific discovery that has not been overturned, acquires a durability that allows it to travel and enter new situations as allegories for complex realities that are remade and reinterpreted outside the site of their production. “This is what allegory always does," writes Law. "It extends the fields of visibility, and crafts new realities out-there" (2004:90). A court ruling that even implies the relationship between soybeans and death might have the mobility and durability to enlarge the situation in which arguments about killer soy escape disqualification.

In 2005, the first case was a response to the attack to which I've already referred, when an eviction raid in a squatter colony next door to Vaquería, called Tekojoja, ended when dozens of houses burned down and two campesinos were killed in a drive-by shooting by soy farmers. ${ }^{8}$ Within hours of the attack, a heated discussion began about how to respond. One group, for example, was ready to burn down the silo that acted as the lynchpin of soy production in the area. But Antonio eventually won out, arguing that the group should take a legal route. Everyone knew that the process would be grueling, although I don't think anyone knew just how much time and energy it would absorb. They were also surprised by how restrictively they had to frame things to appeal to the court. In the end, the court's interest was on a single question: had the campesinos fired on the soy farmers first? The case turned on two primary pieces of evidence: the bullet holes in the sides of one of the soy trucks and my pictures of the event showing that the only weapon the campesinos were carrying was a single slingshot.

For two months, as campesinos poured in from the whole region to create and manage a camp for those displaced by the eviction, almost all the political efforts turned to convincing a handful of prosecutors and judges in remote cities to distribute responsibility, among about $40 \mathrm{men}$, for a single act at a specific place and over a period of about 20 seconds. On the surface, this seemed to radically change the texture of campesino politics, as leaders struggled to squeeze the sprawling complexity of soy politics through the interpretive bottleneck of the criminal court. After several years of targeting soy as a complex and multifaceted invader of the landscape, they moved to cutting out as many relations as possible 
from the story of how the murders had taken place. Whereas before campesinos had often represented soy farmers as the tools of soybeans, the beans had now become irrelevant to the story, as did the eviction, the police, the silo owners, Monsanto, the chemical effluent in the river, the history of violence and rural inequality, and all the ways that beans had articulated these forces together. In other words, to take their claims about soy to court, campesinos had to erase soy, and most of soy's allies, from their claims.

The case was dropped before going to trial. The labor of distilling back the networks of responsibility for the destruction in Tekojoja to a few fingers on triggers did not result in a conviction. But the case did result in enormous media exposure that only rarely called into doubt the responsibility of the shooters. More important, it attracted an expanding number of allies keen to see the case as an allegory for "la soja mata." The deletion of actors from the story allowed for the facts of the case to become more stable, to travel authoritatively in new spheres. The trial circulated beyond the court, and stories published first in local newspapers and then online attracted the interest of anti-GMO activists in Argentina, Spain, Holland, and Canada, who mounted public campaigns against soybeans. These activists, far less shy about being branded as unmodern by Paraguayan elites, descended on Paraguay with banners, books, and websites proclaiming, "La soja mata!" 9 The court had not even considered the responsibility of soybeans, but the longer the case lingered in the media, the more killer soy came into public focus.

It just so happened that another, more complicated case was already making its way through the court system when the shootings happened in Tekojoja. In January 2003, eight-year-old Silvino Talavera had died after being doused twice with herbicides from a crop duster, and two organizations decided to mount a legal case against his neighbors. The case dragged on through appeals, involving bribes and payoffs, inexplicable judicial delays, and even the murder of Silvino's uncle. But the longer the case was delayed, the stronger the network around Silvino's family became. And in the aftermath of the Tekojoja episode, Silvino's family gathered powerful supporters, including a strong campesino women's organization, international letter writers and bloggers, skilled pro bono lawyers, and most unusually, the first pathology lab results to circulate in Paraguay indicating that a likely cause of death was the ingestion of agrotoxins. ${ }^{10}$ The fact of Silvino's murder was established through campesino voices in coordination with those of journalists, foreigners, lawyers, scientists, and judges.

The judges in the case only halfheartedly endorsed the campesino version of events. After four years of legal work and immense expenditure on the part of 
hundreds of people and dozens of organizations, the court responded by finding two farmers criminally negligent and giving them two-year suspended sentences. But far more consequential was the way the case gathered the interests of other political actors who stood far outside the alliances that fought for the case. In 2011, I still heard about Silvino Talavera frequently in Paraguay from people on all sides of the soy question. And it was never a story about two nasty farmers, whose names were never remembered. It was a story about whether soybeans, and the pesticides, equipment, agricultural practices, and demographic changes that come with them, could be held responsible for bad things happening to a vulnerable population. Not everyone agrees that soy killed Silvino, but without my asking, even those who don't agree will bring up the case and make elaborate rationales as to why soy doesn't kill. The labor of distilling responsibility for the trial produced a much more authoritative proposition, international in its reach, about the responsibility of soy, to which many people felt the need to respond.

One of the most telling effects of these cases was the degree to which highly placed spokespeople for soy producers began to publicly attack the campesino version of the story. Two figures in particular gained a reputation for attacking campesinos in national newspapers. Hector Cristaldo (head of a national agricultural producers' organization) took to saying that campesinos had a "mental block" against understanding soybeans as a great opportunity, and Claudia Ruser (president of the Paraguayan Soy Association) claimed that campesino leaders were trying to start a civil war and were using beans as a pretext (see Torres 2007). Both Cristaldo and Ruser were still trying to disqualify campesino claims, but they were also hesitant and defensive. The fact that they had been forced to respond showed that the ground was shifting, and they were taking on new roles as spokespeople, not only for soy producers, but also for soy itself.

That is a radical shift. Starting from a situation in which campesinos were mocked for suggesting that soy was dangerous, we end up with a public debate about the future of Paraguay in which soy is openly attacked and defended as responsible for different effects: economic growth, national modernization, environmental destruction, campesino impoverishment, and death. These beans did not exist before they were enacted in and out of court, but there could be no question of their vital importance afterward. Somewhere a new politics emerged, in the sense meant by Jacques Rancière (1999:99), as a "singular disruption [of the established] distribution of bodies." ${ }^{11}$ By turning killer soy into a matter of national and international concern, campesinos participated in remaking the political landscape, making the presence of beans felt, and forcing new modes of 
thinking among a wider array of actors (Stengers 2010b). This is not to say that everyone suddenly assented to the campesino definition of soy as killer beans. "La soja mata" didn't become a matter of undisputed fact, but it was also not easily disqualified. Instead it became a serious proposition in a wider dialogue of actions and responses.

\section{RESPONSIBLE SOY}

It is tempting to celebrate the campesino movement for this shift and to see the moment as an example of empowerment. Antonio's response to beans was bold, using them as a line of flight from the stifling modern territory of subjects and objects. Through concerted effort campesinos overcame disqualification and forced their allies and adversaries to respond to the very presences they had originally denied existed. ${ }^{12}$ But this in no way implies a complete victory for campesinos; indeed, following Stengers (2010b:21), we might say that what is empowered here is the situation, rather than the actors, and this situation forces campesinos and others to think differently. Although lines of flight are worth taking, by definition they come with no guarantees that the point of arrival will make life easier for people like Antonio (Stengers 2008). This is merely a chapter in a long story of responses that calls forth new responses. There are many possible responses to a newly recognized killer soy and an emboldened campesino movement. This is where I believe that solidarity with Paraguayan campesinos demands a response that is not simply a ratification.

I wonder, in fact, if the greater danger for campesinos in this new position isn't the temptation to use disqualification themselves. This first occurred to me after an incident in 2009 in a community not far from Antonio's house. A soy farmer had signed a contract with his neighbors saying he would not plant soybeans on a disputed plot of land. He broke the contract, and confronted by campesino protesters, he called in the police, who looked over the agreement. "Why don't you plant something else?" the policeman asked him, innocently. "Why don't you plant corn?" The soy farmer, beside himself with frustration, threw a tantrum. With his face twisted in rage, he yelled, "I only want to plant soy! I want to plant soy!" before jumping in his truck and careening off down the road. The story about the man's breakdown circulated for weeks among my friends and took on a familiar tone. It became a mocking story of the farmer blinded by his love of soybeans. Why not, said the reasonable storytellers, just plant corn? There was something disingenuous in this disqualification, and it made me wonder whether it foreclosed other kinds of thinking that might foster, for example, 
stronger alliances between campesinos and impoverished soy producers who lived nearby.

I had a similar reaction to the decidedly ambivalent appearance of something calling itself "Responsible Soy" in the South American soy belt. Responsible Soy refers to a nonbinding declaration of principles by producers that the beans will be accompanied by reforestation efforts, fair labor practices, and a commitment to not kill one's neighbors, with the promise of implementing country-specific certification guidelines in the coming years. ${ }^{13}$ Activists are quick to accuse Responsible Soy of being a greenwash and claim that the discourse of responsibility is a direct challenge to the state, an attempt to reposition the corporate bodies in and around the soy complex as the proper site of government in lieu of an absent regulatory apparatus (Corporate Europe Observatory 2009). Indeed, the guidelines in most cases amount to little more than a declaration that farmers will respect national laws and regulations, explicitly moving the center of regulatory responsibility from the state to corporations and to enforcement by the market. Certainly this is part of what is going on.

But it is not the whole story. If, alongside campesinos, we respond to killer soy - if we tie our analytic intervention to the enactment of a historically specific responsible thing - then this has consequences for how we view other soys. Responsible Soy, an industry proposition that recognizes harm and enlists a new form of regulation, deserves a more careful response than disqualification. ${ }^{14}$ When I asked Antonio what he thought of Responsible Soy, I expected him to oppose it, but I didn't expect mockery. "I always tell people how ridiculous it is. Soy can't be responsible," he said. "Soy can't talk!” The phrase “soy can't talk” (“soja noñe’ ẽkuaai”) evokes a common campesino expression for lacking intelligence. It also repeats the modern refrain, a standard kind of disqualification used to exclude things from political and moral consideration. ${ }^{15}$ Antonio and others clearly took pleasure in accusing soy farmers and their corporate allies of either being blind themselves or of trying to pull one over on the world with a blatant misallocation of agency to beans.

But who in fact wins from this new form of disqualification? When I returned to visit Antonio in 2009, they were not all dead, as he had predicted. But some certainly were, including Antonio's wife of 20 years. She had died of a disease that was entirely treatable, if not for her family's poverty, undeniably sharpened by beans. Others had left the countryside to flee deepening poverty and, for all intents and purposes, ceased being campesinos. Everything he said then was tinged with 
melancholy and resignation. The same was true of his insistence that beans don't talk.

A less celebratory reading of this story begins by noting that the campesino flight from the modern, like their flight from the frontier, may have been a response forced by soybeans. On the front lines of a dramatic material transformation of the landscape, campesinos had merely been the first to appreciate a fundamental shift engulfing their country from the east. Their response, like all responses, was shaped by proximity. By 2009, many more people had been touched by this presence, and a new form of thinking had engulfed even Asunción. Paraguay was now a place full of killer beans and responsible beans, of newly flexible networks of capital, government agents, and NGOs all unselfconsciously seeing rural development as a form of technical negotiation with these miraculous and destructive legumes. But far from appearing as the leaders of this negotiation, campesinos have retaken their place as subalterns on a new terrain. My doubt now is that another form of disqualification is emerging with a different relationship to the modern than what Stengers warns against. Antonio's attempts at disqualification ring hollow and confirm another story so common among Andrés's friends: campesinos are the dupes not only of superstition but of a quaint form of high modernism, the same ideology that keeps them demanding state subsidies for cotton or keeps them thinking that a citizen's hard work and honesty entitles him to basic police protections and opportunities for improvement. Only a campesino could believe these things, the line goes, and only a campesino could believe that it was possible to just plant corn.

\begin{abstract}
This article provides an ethnographic response to the statement that soy kills ("la soja mata"), a refrain often repeated by campesino activists living on the edge of Paraguay's rapidly expanding soybean frontier. In the context of Paraguay's modernization projects since the 1960s, statements like these were easily disqualified as irrational or nonmodern. In the process, the political importance and analytic potential of the beans were dismissed, and so, too, were the lives and analyses of rural activists. And yet the activists with whom I worked managed, over the course of five years of court battles, to bring killer beans before the courts and to have them recognized as a force in Paraguayan politics. In so doing, they also opened up an analytic position for ethnography, allied with Isabelle Stengers's cosmopolitics, which emerges from a situation of mutually enacting responses, rather than as a mediator of relationships between beings included or excluded from the political territory by the criteria of modernity. [legal activism, response, responsibility, knowledge practices, modernity, human-plant relations, frontiers, agrarian transitions, rural politics]
\end{abstract}




\section{NOTES}

Acknowledgments. This article would not have been possible without the ongoing friendship of Antonio Galeano and Irene Ramírez, among innumerable others in Paraguay with whom I have learned to think. I am also grateful for the many careful readings that versions of this article received from Marisol de la Cadena, Bettina Ng'weno, Tim Choy, Anna Tsing, Mario Blaser, Tania Li, Krystyna Sieciechowicz, Jeremy Campbell, Kristina Lyons, Brian Noble, and Isabelle Stengers, as well as Anne Allison and Charles Piot and two anonymous reviewers. I also received invaluable feedback from audiences at the University of California at Davis, Dalhousie University, and meetings of the American Anthropological Association and the Society for Cultural Anthropology, in particular from Joe Dumit, Alan Klima, James Smith, Glenn Stone, Liz Fitting, Birgit Mueller, Chris Kortright, Natasha Myers, Sarah Whatmore, and John Law. My research was funded in part by the Wenner-Gren Foundation and the Social Sciences and Humanities Research Council of Canada.

1. That being said, the concept of response has also historically been used to describe inherent capacities and to differentiate humans from nonhumans, which can only "react." Derrida (2002) and Haraway (2008), among others, have opened up the conception of response for nonhuman animals.

2. Many of the authors I cite here go to some lengths to uncouple the word from its humanist underpinnings, making it a property of any number of hybrids and quasi objects, including humans. Barad's (2007) notion of the "agential cut" is probably the most sophisticated version. I am not convinced that there is anything worth salvaging from the concept of agency that cannot be done using other, better words.

3. Barad uses the term intra-action to talk about relationships that are not the interactions of previously existing entities but entities mutually constituted in process.

4. RR Soybeans are profitable primarily because, by resisting the herbicide glyphosate (Roundup), they allow repeated applications and virtually eliminate the need for manual weeding.

5. The practice was common enough that the nickname "white bag," was used across the ministry to describe seed shipments that arrived without any information about their providence.

6. Indeed, although Paraguay failed to meet most of the conditions set by the IMF for a standby loan in 2004, the fund nonetheless awarded the money on the basis of positive growth after a good soy year. Economists call this kind of dependency the "resource curse" (see Berry 2010), clearly placing responsibility on nonhumans.

7. I'm using Disch's (2010) translation here of épreuves de force, rather than the more common "trials of strength," which connotes a property rather than an active relationship.

8. See Hetherington 2011 for a detailed discussion of the land conflicts surrounding this case.

9. See www.lasojamata.net.

10. Until 2009, when the new government reformed the public health system, there was almost no discussion about pesticide poisoning outside of the relatively frequent use of pesticides for suicide. The Talavera case remains the only case in which blood tests were carried out to ascertain the likelihood of poisoning.

11. This requires a slight modification of Rancière, who for the most part contains his version of politics to the realm of humans (see Bennett 2010:104-107).

12. There's a strong argument to be made that campesinos, together with soybeans, contributed significantly to the 2008 election of the first nominally leftist government in Paraguay's history.

13. The initiative, called the Round Table on Responsible Soy, brings together corporations and NGOs throughout the Southern Cone. In Paraguay, the organizations involved are the World Wildlife Fund and an investment consortium called Grupo DAP. See www.responsiblesoy.org.

14. The same goes for attempts to fortify the mixed economies of the campesino sector, to generate more viable local food networks, and to improve value-added capacity in crops other than soybeans that can be profitably produced by smallholders.

15. Disch (2010:271) makes this point most strongly, showing that the "mythology of voice" as an unmediated capacity of (certain) humans, operates in the same way I describe agency. 


\section{REFERENCES CITED}

Baer, Werner, and Melissa H. Birch

1984 Expansion of the Economic Frontier: Paraguayan Growth in the 1970s. World Development 12(8):783-798.

Barad, Karen Michelle

2007 Meeting the Universe Halfway: Quantum Physics and the Entanglement of Matter and Meaning. Durham, NC: Duke University Press.

Bennett, Jane

2010 Vibrant Matter: A Political Ecology of Things. Durham, NC: Duke University Press.

Berry, Albert

2010 Elements of an Employment Strategy for Paraguay. In Losing Ground in the Employment Challenge. A. Berry, ed. Pp. 11-30. New Brunswick, NJ: Transaction.

Corporate Europe Observatory

2009 "Responsible Soy" in Paraguay: Grupo DAP and the Advancement of Soy Monocultures in San Pedro. http://corporateeurope.org/sites/default/files/sites/ default/files/files/resource/GrupoDAP_article_ES_0.pdf, accessed November 8, 2012.

de Sousa, Ivan Sergio Freire, and Rita de Cassia Milagres Teixeira Vieira

2008 Soybeans and Soyfoods in Brazil: Sketch of an Expanding World Commodity. In The World of Soy. C. M. Du Bois, C. B. Tan, and S. W. Mintz, eds. Pp. 234-256. Urbana: University of Illinois Press.

Deleuze, Gilles, and Félix Guattari

1988 A Thousand Plateaus: Capitalism and Schizophrenia. London: Athlone.

Derrida, Jacques

2002 And If the Animal Answered. Aut Aut (310-311):4-26.

Disch, Lisa

2010 Faitiche-izing the People. In Political Matter. S. Whatmore and B. Braun, eds. Pp. 267-295. Minneapolis: University of Minnesota Press.

Domínguez, Ramiro

1975 [1967] El Valle y la Loma; Comunicación en comunidades rurales. Asunción: Editorial EMASA.

Fogel, Ramón, and Marcial Riquelme

2005 Enclave Sojero: Merma de soberanía y pobreza. Asunción: CERI.

Frutos, Juan Manuel

1982 Con el hombre y la tierra hacia el bienestar rural. Asunción: Cuadernos Republicanos.

Fuller, Steve

1994 Making Agency Count: A Brief Foray into the Foundations of Social Theory. American Behavioral Scientist 37(6):741-753.

Hacking, Ian

1983 Representing and Intervening: Introductory Topics in the Philosophy of Natural Science. Cambridge: Cambridge University Press.

Haraway, Donna Jeanne

2008 When Species Meet. Minneapolis: University of Minnesota Press.

Hetherington, Kregg

2011 Guerrilla Auditors: The Politics of Transparency in Neoliberal Paraguay. Durham,

Keane, Webb

NC: Duke University Press.

1997 From Fetishism to Sincerity: On Agency, the Speaking Subject, and Their Historicity in the Context of Religious Conversion. Comparative Studies in Society and History 39(4):674-693.

Kleinpenning, J. M. G.

1987 Man and Land in Paraguay. Amsterdam: CEDLA. 
Laidlaw, James

2010 Agency and Responsibility: Perhaps You Can Have too Much of a Good Thing. In Ordinary Ethics: Anthropology, Language and Action. M. Lambek, ed. Pp. 143-164. New York: Fordham University Press.

Latour, Bruno

1999 Pandora's Hope: Essays on the Reality of Science Studies. Cambridge, MA: Harvard University Press.

2004 Politics of Nature: How to Bring the Sciences into Democracy. Cambridge, MA: Harvard University Press.

2010 The Making of Law: An Ethnography of the Conseil d'Etat. Cambridge: Polity.

Law, John

2004 After Method: Mess in Social Science Research. London: Routledge.

2011 Knowledge Places. Heterogeneities 1. http://www.heterogeneities.net/ publications/Law2011knowledgePlaces.pdf, accessed November 8, 2012.

Nickson, Andrew, and Peter Lambert

2002 State Reform and the "Privatized State" in Paraguay. Public Administration and Development 22(2):163-174.

Pastore, Carlos

1972 La lucha por la tierra en el Paraguay. Montevideo: Editorial Antequera.

Rancière, Jacques

1999 Disagreement: Politics and Philosophy. Minneapolis: University of Minnesota Press.

Riles, Annelise

2006 Introduction: Anthropology in Response. In Documents. Ann Arbor: University of Michigan Press.

Robin, Marie-Monique

2008 The World According to Monsanto. Halifax, NS: Fernwood.

Souchaud, Sylvain

2002 Pionniers brésiliens au Paraguay. Paris: Karthala.

Stengers, Isabelle

2008 Experimenting with Refrains: Subjectivity and the Challenge of Escaping Modern Dualism. Subjectivity 22:38-59.

2010 Cosmopolitics. Minneapolis: University of Minnesota Press.

2010 Including Nonhumans in Political Theory: Opening Pandora's Box? In Political Matter. S. Whatmore and B. Braun, eds. Pp. 3-34. Minneapolis: University of Minnesota Press.

Torres, Gustavo

2007 Informe Especial: El negocio de la soja y la trampa de los agrotóxicos en Paraguay. Zoom: Buenos Aires. http://revista-zoom.com.ar/articulo1944.html, accessed November 4, 2011.

Tsing, Anna

N.d. Unruly Edges: Mushrooms as Companion Species. http://tsingmushrooms. blogspot.ca/2010/11/anna-tsing-anthropology-university-of.html, accessed November 8, 2012.

Turner, Brian

1993 Community Politics and Peasant-State Relations in Paraguay. Lanham, MD: University Press of America.

Wagner, Carlos

1990 Brasiguaios: Homens sem pátria. Petrópolis: Editora Vozes.

White, Richard Alan

2004 Breaking Silence: The Case that Changed the Face of Human Rights. Washington, DC: Georgetown University Press. 